\title{
FILTERISASI MEDIA BERPORI DAN BERBUTIR DALAM PERAN SANITASI LINGKUNGAN TERHADAP AIR LIMBAH BERBASIS BAHAN ORGANIK MIE INSTAN
}

\author{
Zetly E. Tamod*)
}

\section{ABSTRACT}

\section{Tamod, Z.E. 2005. Porous Medium Filters as Environmental Sanitation Instrument of Instant Noodle Plant's Liquid Waste Water Based on the Organic Mater. Eugenia 11 (1) : 60-73.}

The Riset porous medium filters and granulate as environmental sanitation instrument of instant noodle plant's liquid waste based of organic mater as problems solution industrial plants north sulawesi on cleaning their liquid waste so as not to contaminate the surrounding environment and on recycling or cleaning the waste in order to efficiently reuse it. Liquid waste of instant noodle consists of the organic-liquid waste based on the raw materials from agriculturecultivation, like : flour (contain of carbohydrate, protein, vitamin and mineral organic compounds) and coconut oil (contain of the fat acids like laurate, palmitate, and oleate). The aims of this experiment are to evaluate the ability of sand+clay and clay+charcoal dust mixtures as porous medium filters and to apply briquette in liquid waste recycling processes. Variables to be determined are suspended and soluble materials, acidity, electrical conductivity, BOD, COD, organic material, cation exchange capacity, soluble oxygen, nitrate, turbidity, particle distribution, permeability. The experiment will be designed as a Completely Randomised, 3 replicates, and 3 treatments. Among the applied treatments are sand (T1), clay (T2), 60\% clay+charcoal dust mixture (T3). Analysis of variance (ANOVA), Duncan's Multiple Range Test (DMRT). The results of this research show that, the porous and grained medium from sand (T1), clay (T2) and clay + active charcoral dust mixture (T3) can be used as the environmental sanitation instrument on the Indofood instant noodle liquid waste based of organic mater.

Keywords : filters, liquid waste

\section{PENDAHULUAN}

Air yang terpolusi menunjukkan telah terjadi penyimpangan sifat-sifat air dari keadaan normal, artinya berbeda dengan kemumian asal air tersebut. Penggunaan dan pembuangan senyawa-senyawa kimia ke dalam suatu lingkungan akan mengalami berbagai proses yaitu, proses penguapan, proses perombakkan baik secara kimia atau biologi, proses jerapan oleh partikel tanah dan serapan oleh akar tanaman, proses pengangkutan oleh alir- an air permukaan, dan proses oleh air perkolasi.

Kebanyakkan industri yang membuang air hasil olahan memiliki ciri-ciri air yang terpolusi sangat bervariasi tergantung dari jenis air dan polutannya atau komponen yang mengakibatkan polusi. Eckenfelder (1985) menggolongkan berbagai variabel yang dapat digunakan sebagai tolok ukur penilaian kualitas lingkungan perairan yaitu BOD (Biological Oxygen Demand) sebagai jumlah oksigen yang dibutuhkan oleh mikroba untuk menguraikan hampir semua zat organis yang

" Jurusan Tanah, Fakultas Pertanian UNSRAT Manado, 95115 
terlarut dan sebagian zat-zat organis yang tersuspensi dalam air, COD (Chemical Oxygen Demand) sebagai jumlah oksigen yang dibutuhkan untuk mengoksidasi zatzat organik yang ada dalam satu liter sampel air dengan pengoksida $\mathrm{K}_{2} \mathrm{Cr}_{2} \mathrm{O}_{7}$, TOD (Total Oxygen Demand) dan TOC (Total Organic Carbon) merupakan ukuran kandungan senyawa organik keseluruhan, Padatan tersuspensi (suspended solids), $\mathrm{pH}$ larutan, kandungan padatan keseluruhan, kandungan nitrogen dan fospor, dan kandungan logam berat.

Industri/pabrik mie instan PT. Indofood Sukses Makmur Tbk. yang terletak di Kelurahan Madidir Urer, Kota Bitung, Propinsi Sulawesi Utara merupakan salah satu yang menghasilkan limbah bahan organik, karena air limbah yang dimaksud merupakan limbah cair organik berbasis bahan baku dari olahan pertanian, seperti tepung terigu (mengandung senyawa organik karbohidrat, protein, vitamin dan mineral) dan minyak kelapa (mengandung asam lemak diantaranya laurat, palmitat dan oleat) yang terlarut dalam air limbah. Berdasarkan hasil analisis Balai Penelitian dan Pengembangan Industri Manado (Balitri) Tahun 2000 (konsultasi pribadi) memiliki bentuk fisik berminyak $31 \mathrm{mg} /$, COD $913 \mathrm{mg} / \mathrm{l}$, BOD $346 \mathrm{mg} / \mathrm{l}$ dan $\mathrm{pH}$ 5,2 telah menunjukkan di atas ambang baku mutu limbah cair Kep-51/MENLH/10/1995 masing-masing (I) $5,100,50 \mathrm{mg} / \mathrm{l}$ dan (II) $10,300,150 \mathrm{mg} / \mathrm{l}$ dengan $\mathrm{pH} 6,0-9,0$. Sifat dari limbah tersebut, menunjukkan perlu dilakukan pengolahan sebelum dibuang ke lingkungan sekitar, termasuk pemanfaatannya kembali.

Permasalahan diatas, mendorong peneliti untuk melakukan penelitian dalam bidang teknologi pengendalian dan penanganan limbah cair organik melalui eksperiment murni jangka pendek. Sistem yang diteliti masih tergolong sederhana dan murah karena bahan bakunya ter- sedia, dengan memanfaatkan media berpori dan berbutir sebagai filter. Misalnya lempung, peneliti mencoba melihat bagaimana kemampuan tanah lempung di daerah Sulawesi Utara lut dicampur dengan dust arang aktif produk lokal yang banyak dijumpai pada tanah-tanah di daerah tropis, umumnya mengandung allophane. Sementara potensi pasir daerah yang merupakan hasil dari abu vulkan gunung berapi juga menjadi bahan perbandingan sebagai bahan penyaring limbah. Nugroho (2001) mengutip Babich and Stotzki (1978) menilai bahwa lempung yang didominasi oleh jenis mineral liat sangat berpengaruh terhadap pengikatan logam berat. Sementara Anonimous (2002) meneliti media pasir, karbon aktif dengan suatu sistem perekat yang dicetak dalam bentuk briket mampu memperbaiki kualitas air yang akan dikonsumsi.

\section{METODE PENELITIAN}

\section{Tempat dan Waktu Penelitian}

Penelitian ini dilaksanakan di Laboratorium Jurusan Tanah Fakultas Pertanian Unsrat, Balai Laboratorium Kesehatan dan Balai Riset dan Standarisasi Industri dan Perdagangan Manado. Tempat pengambilan sampel pasir dari tanah entisol di Bitung dan lempung dari tanah campuran andisol dan latosol Rurukan Tondano, dengan dust arang aktif di peroleh dari PT Mapalus Makawanua Charcoal Industry (MMCL) Bitung sebagai bentuk hasil samping limbah dari perusahaan tersebut dan air limbah berasal dari limbah cair Pabrik Mie Instan PT. Indofod Sukses Makmur Tbk.

Waktu pelaksanaan penelitian yaitu dari Bulan Nopember 2002 - Mei 2003.

\section{Bahan dan Alat}

Bahan pasir lolos ayakan $\pm 0,5$ $\mathrm{mm}$, fraksi lempung lolos ayakan \pm 100 
mesh (Foth 1994) dan campuran lempung dan debu (dust) arang aktif yang $90 \%$ lolos ayakan \pm 100 mesh dan dijadikan briket dengan menggunakan tepung kanji. Limbah cair berbasis bahan organik berasal dari efluen Pabrik Mie Instan PT Indofod Sukses Makmur Tbk. Dan dianalisis dengan menggunakan bahan diantaranya aquades, batu didih, asam sulfat pekat, $\mathrm{HgSO}_{4}\left(\mathrm{~K}_{2} \mathrm{Cr}_{2} \mathrm{O}_{7}\right.$, Feroin, mangan sulfat, Alkalijodidaazida, larutan thiosulfat, indikator kanji amilum, larutan brusin asam sulfanilat, Larutan baku nitrat, alum.

Peralatan yang digunakan adalah termometer, $\mathrm{pH}$ meter, tandon pengambilan air limbah, karung goni untuk pengambilan sampel tanah cara biasa, sekop, kantong plastik untuk dust arang tempurung, oven pengering/tanur, timbangan analitik, pengaduk, pipet, gelas piala, rancangan alat yang terdiri atas rak kayu tempat mengatur cuplikan media berbutir dan berpori dalam pipa Flexy glass diameter $10 \mathrm{~cm}$, wadah terukur erlemeyer 1 liter, tandon yang berisi air limbah, tabung pengendapan air limbah. corong pisah, pipet, erlenmeyer, botol winkler, buret, pemanas listrik, alat refluks, gelas piala, alat destilasi, spektrofotometer, saringan, labu Kyeldahl, alat destilasi, alat titrasi, colorimeter, labu ukur, beaker $250 \mathrm{ml}$, gelas arloji, corong erlemeyer, alat penetapan permeabilitas, gelas ukur, timbangan analitik, satu set ayakan, cawan porselin, tabung reaksi.

\section{Metode Penelitian}

Penelitian ini menggunakan metode kausal komparatif yaitu dengan menganalisa kemungkinan sebab akibat berdasarkan hasil analisis dalam suatu metode percobaan di lapangan dan dalam laboratorium. Rancangan percobaan yang digunakan adalah rancangan acak lengkap (RAL) (Heryanto 1996) untuk masing-ma- sing tiga ulangan, Faktor perlakuan adalah, terdiri atas perilaku 3 media berbutir dan berpori yaitu pasir (T1), lempung (T2) lempung konsentrasi $60 \%$ dicampur dust arang tempurung (T3). Data limbah sesudah diperlakukan dianalisis secara statistik dengan analisis varian. Perbedaan antar perlakuan ditentukan dengan Duncan's Multiple Range Test (Gaspersz 1995 ; Gomez dan Gomez 1995).

\section{Prosedur Penelitian}

\section{Penelitian Observasional}

a. Mendeskripsikan ciri-ciri kualitas limbah cair dari Pabrik Mie Instan Indofood dengan mengukur variabel $\mathrm{pH}$, DHL, BOD, COD, Nitrat, DO, kekeruhan, Zat Organik, TDS, \& TSS.

b. Menginventarisir kemampuan tiga media berbutir dan berpori dengan mendeskripsi ciri-cirinya seperti tekstur, prmeabilitas, pH, BO, KTK.

c. Pembuatan alat cetak pengepres tipe ulir kemudian melakukan pembuatan briket.

\section{Penelitian Eksperimental}

a. Menstabilisasi air limbah sebagai bentuk pengolahan pendahuluan.

b. Menguji perilaku media berbutir dan berpori terhadap daya sanitasi limbah cair sebagai pengolahan lanju$\tan$

c. Dilakukan perbandingan air yang dihasilkan pada pengolahan kedua berdasar Persyaratan Air Bersih (PERMENKES No. 416/MENKES/ PER/XJ 1990) dan Baku Mutu Air Limbah (KEPMENLH No. 51/ MENLH/10/1995) serta untuk Pengelolaan Kualitas Air dan Pengendalian Pencemaran Air (Peraturan Pemerintah RI Nomor 82 Tahun 2001). 


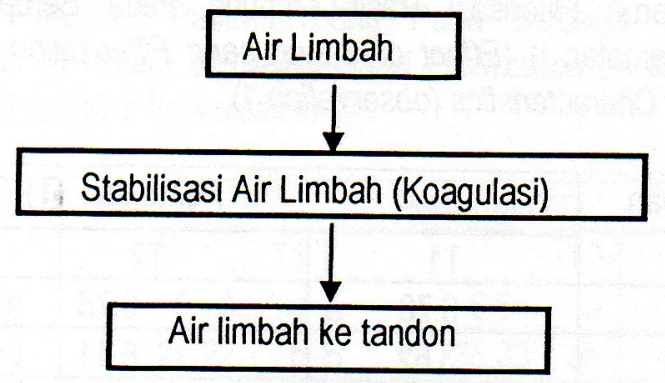

Gambar 1. Skema Penelitian Eksperiment Pengolahan Pendahuluan (Scheme of the Research of the Previous-Cultivation Experiment)

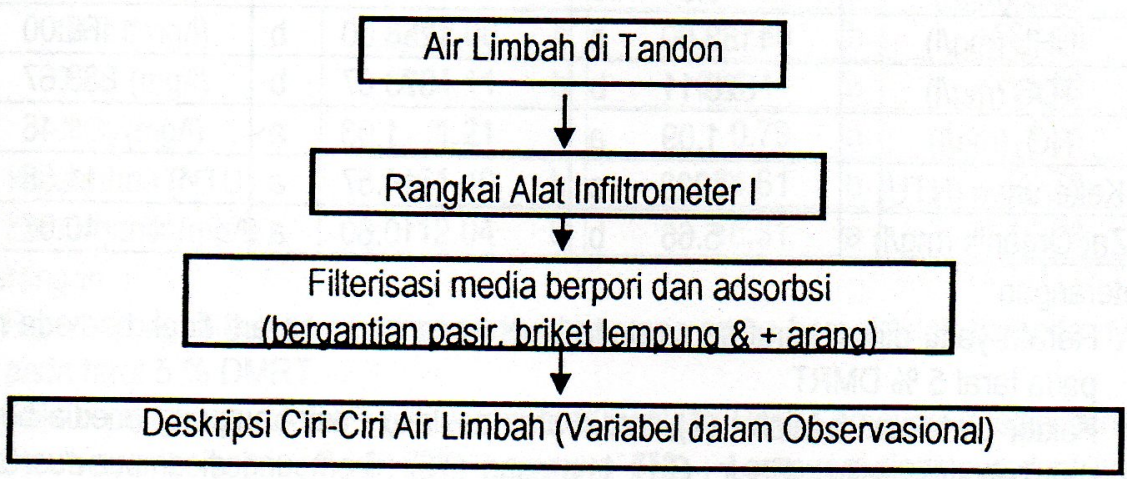

Gambar 2. Skema Penelitian Eksperiment Pengolahan Lanjutan (filterisasi) (Scheme of the Research of the Continous-Cultivation Experiment (filterization)

\section{HASIL DAN PEMBAHASAN}

Hasil analisis sifat-sifat air limbah sebelum pengolahan menunjukkan beberapa variabel utama seperti $\mathrm{pH} 5,6, \mathrm{BOD}$ $641 \mathrm{mg} / \mathrm{l}$ dan COD $1928 \mathrm{mg} /$, telah melewati Baku Mutu Limbah Cair (Kep-51/ MENLH/10/95), Persyaratan Air Bersih berdasar Permenkes RI No. 416/Menkes/ per/1990 dan berdasar Peraturan Pemerintah RI No, 82 tahun 2001 tentang Pengelolaan Kualitas Air dan Pengendalian Pencemaran Air. Sementara kekeruhan mencapai 50 NTU, telah melewati batas maksimum dari baku mutu air limbah $(25$ NTU). Untuk TDS $1000 \mathrm{mg} /$ telah mencapai batas marginal persyaratan Pengelolaan Kualitas Air (1500 mg/l) dan Pengendalian Pencemaran Air (1000 mg/l). Sedangkan TSS $(90,2 \mathrm{mg} / 1)$ telah melewati pada batas kelas I dan II pengelolaan kualitas air dan pengendalian pencemaran air (50 mg/l). Untuk DHL (1100 mg/l) berdasar klasifikasi air ditinjau dari konsentrasi garam (<175 - >2100 mg/l) menggunakan klasifikasi Summers dan Schawb (1970) dalam Kodoatie (1996) telah masuk klasifikasi diizinkan, sedangkan nilai Oksigen Terlarut (DO, $5,2 \mathrm{mg} / \mathrm{l})$ berada pada batas minimal antara kelas I $(6 \mathrm{mg} / 1)$ dan II (4 mg/l) persyaratan Pengelolaan Kualitas Air dan Pengendalian Pencemaran Air.

Pengamatan perubahan sifat-sifat air limbah setelah dilakukan filterisasi media berpori dan berbutir dalam perilaku pasir lempung untuk setiap pengamatan disajikan dalam Tabel 1, 2 dan 3, dan seperti yang tampak dalam lampiran 1 untuk ratarata sifat air limbah setelah dilakukan filterisasi pasir-lempung pada ketiga pengamatan. 
Tabel 1. Pengaruh Filterisasi Pasir-Lempung Pada Berbagai Sifat Air Limbah (Pengamatan I) (Effect of Clayey-sand Filterization on the Various Waste Water Characteristics (observation 1)

\begin{tabular}{|c|c|c|c|c|c|c|}
\hline \multirow[t]{2}{*}{ Sifat Air Limbah } & \multicolumn{6}{|c|}{ Perlakuan $(\mathrm{T})$} \\
\hline & T1 & & T2 & & T3 & \\
\hline $\mathrm{PH}$ & 6.78 & a & 6.78 & a & 6.74 & a \\
\hline TSS (mg/l) & 3.62 & c & 6.11 & b & 8.17 & a \\
\hline $\mathrm{COD}(\mathrm{mg} / \mathrm{l})$ & 157.00 & c & 500.89 & $b$ & 693.89 & $a$ \\
\hline $\mathrm{BOD}(\mathrm{mg} / \mathrm{l})$ & 33.44 & b & 103.00 & $a$ & 135.33 & $a$ \\
\hline $\mathrm{DO}(\mathrm{mg} / \mathrm{l})$ & 5.91 & $\mathrm{aa}$ & 6.20 & $a$ & 5.62 & $b$ \\
\hline $\mathrm{DHL}(\mathrm{mg} / \mathrm{l})$ & 1168.00 & $c$ & 1258.00 & $b$ & 1468.00 & a \\
\hline TDS (mg/l) & 628.11 & $b$ & 673.67 & $b$ & 833.67 & a \\
\hline $\mathrm{NO}_{3}(\mathrm{mg} / \mathrm{l})$ & 1.09 & $a$ & 1.03 & a & 1.46 & $a$ \\
\hline Kekeruhan (NTU) & 6.923 & c & 14.57 & a & 11.58 & $b$ \\
\hline Zat Organik (mg/l) & 5.66 & $b$ & 10.60 & a & 10.07 & $\mathrm{a}$ \\
\hline
\end{tabular}

Keterangan :

1) Rerata yang diikuti huruf sama pada baris yang sama berarti tidak berbeda nyata pada taraf $5 \%$ DMRT

2) Faktor perlakuan adalah : (T), terdiri atas perilaku Pasir-Lempung (media berbutir dan berpori) yaitu : Pasir (T1); Lempung (T2) ; Lempung dicampur dust arang tempurung (T3).

Pada pengamatan I dalam Tabel 1 terlihat bahwa perubahan sifat air limbah yaitu TSS, COD, DHL, dan Kekeruhan menunjukkan pengaruh yang berbeda untuk setiap pe rlakuan T1, T2 dan T3. Sementara $\mathrm{pH}$ dan $\mathrm{NO}_{3}$ untuk ketiga perlakuan $\mathrm{T} 1, \mathrm{~T} 2$ dan $\mathrm{T} 3$ menunjukkan nilai yang hampir sama dan ditunjukkan oleh huruf yang sama mengikutinya. Ini berarti perlakuan T pada pengamatan I memberikan pengaruh yang sama terhadap respons output sifat air limbah $\mathrm{pH}$ dan $\mathrm{NO}_{3}$. Sifat air limbah yang diikuti huruf sama dan menunjukkan pengaruh tidak berbeda adalah BOD pada perlakuan $T 2$ dan $T 3$, TDS pada perlakuan $\mathrm{T} 1$ dan $\mathrm{T} 2$, dan DO perlakuan $T 1$ diikuti huruf yang sama dari T2 dan T3. 
Tamod, Z.E. : Filterisasi Media Berpori dan Berbutir .

Tabel 2. Pengaruh Filterisasi Pasir-Lempung Pada Berbagai Sifat Air Limbah (Pengamatan II) (Effect of Clayey-Sand Filterization on the Various Waste Water Characteristics (observation 2)

\begin{tabular}{|c|rr|rr|rr|}
\hline \multirow{2}{*}{ Sifat Air Limbah } & \multicolumn{5}{|r|}{ Perlakuan (T) } \\
\cline { 2 - 7 } & & $\mathrm{T} 1$ & $\mathrm{~T} 2$ & $\mathrm{~T}$ \\
\hline $\mathrm{PH}$ & 6.78 & $\mathrm{a}$ & 6.64 & $\mathrm{a}$ & 6.81 & $\mathrm{a}$ \\
\hline $\mathrm{TSS}(\mathrm{mg} / \mathrm{l})$ & 27.22 & $\mathrm{~b}$ & 35.33 & $\mathrm{ab}$ & 44.11 & $\mathrm{a}$ \\
\hline $\mathrm{COD}(\mathrm{mg} / \mathrm{l})$ & 448.89 & $\mathrm{c}$ & 1019.56 & $\mathrm{~b}$ & 1473.56 & $\mathrm{a}$ \\
\hline $\mathrm{BOD}(\mathrm{mg} / \mathrm{l})$ & 81.78 & $\mathrm{c}$ & 200.78 & $\mathrm{~b}$ & 291.78 & $\mathrm{a}$ \\
\hline $\mathrm{DO}(\mathrm{mg} / \mathrm{l})$ & 4.40 & $\mathrm{a}$ & 4.37 & $\mathrm{a}$ & 4.40 & $\mathrm{a}$ \\
\hline $\mathrm{DHL}(\mathrm{mg} / \mathrm{l})$ & 1212.00 & $\mathrm{c}$ & 1353.00 & $\mathrm{~b}$ & 1588.00 & $\mathrm{a}$ \\
\hline $\mathrm{TDS}(\mathrm{mg} / \mathrm{l})$ & 654.11 & $\mathrm{~b}$ & 621.44 & $\mathrm{~b}$ & 791.89 & $\mathrm{a}$ \\
\hline $\mathrm{NO}_{3}(\mathrm{mg} / \mathrm{l})$ & 1.21 & $\mathrm{a}$ & 0.79 & $\mathrm{a}$ & 1.04 & $\mathrm{a}$ \\
\hline Kekeruhan $(\mathrm{NTU})$ & 61.49 & $\mathrm{~b}$ & 64.61 & $\mathrm{~b}$ & 76.78 & $\mathrm{a}$ \\
\hline Zat Organik (mg/l) & 12.04 & $\mathrm{~b}$ & 16.31 & $\mathrm{a}$ & 18.08 & $\mathrm{a}$ \\
\hline
\end{tabular}

Keterangan :

1) Rerata yang diikuti huruf sama pada baris yang sama berarti tidak berbeda nyata pada taraf $5 \%$ DMRT

2) Faktor perlakuan adalah : $(T)$, terdiri atas perilaku Pasir-Lempung (media berbutir dan berpori) yaitu : Pasir (T1); Lempung (T2) ; Lempung dicampur dust arang tempurung (T3).

Tabel 2 menggambarkan adanya perubahan yang berbeda untuk perlakuan T1 T2 dan T3 dari sifat air limbah COD, $\mathrm{BOD}, \mathrm{DHL}$. Sementara $\mathrm{pH}$ DO dan $\mathrm{NO}_{3}$ untuk ketiga perlakuan $\mathrm{T} 1, \mathrm{~T} 2$ dan $\mathrm{T} 3 \mathrm{me}-$ nunjukkan nilai yang hampir sama dan ditunjukkan oleh huruf yang sama mengikutinya. Ini berarti perlakuan T pada pengamatan 2 memberikan pengaruh yang

sama terhadap respons output sifat air limbah $\mathrm{pH}, \mathrm{DO}$ dan $\mathrm{NO}_{3}$. Untuk sifat air limbah yang diikuti huruf sama dan menunjukkan pengaruh yang tidak berbeda adalah TDS dan Kekeruhan pada perlakuan T1 dan T2, Zat Organik pada perlakuan $T 2$ dan T3, sedangkan TSS perlakuan $\mathrm{T} 2$ diikuti huruf yang sama dari $\mathrm{T} 1$ dan $\mathrm{T} 3$. 
Tabel 3. Pengaruh Filterisasi Pasir-Lempung Pada Berbagai Sifat Air Limbah (Pengamatan III) (Effect of Clayey-Sand Filterization on the Various Waste Water Characteristics (observation 3)

\begin{tabular}{|c|rr|rr|rr|}
\hline Sifat Air Limbah & \multicolumn{5}{|r|}{ Perlakuan (T) } \\
\hline & & $\mathrm{T} 1$ & & $\mathrm{~T} 2$ & $\mathrm{~T} 3$ \\
\hline $\mathrm{PH}$ & 6.65 & $\mathrm{a}$ & 6.60 & $\mathrm{a}$ & 6.67 & $\mathrm{a}$ \\
\hline $\mathrm{TSS}(\mathrm{mg} / \mathrm{l})$ & 17.43 & $\mathrm{~b}$ & 12.17 & $\mathrm{c}$ & 20.49 & $\mathrm{a}$ \\
\hline $\mathrm{COD}(\mathrm{mg} / \mathrm{l})$ & 571.80 & $\mathrm{~b}$ & 1303.10 & $\mathrm{a}$ & 1490.30 & $\mathrm{a}$ \\
\hline $\mathrm{BOD}(\mathrm{mg} / \mathrm{l})$ & 135.11 & $\mathrm{a}$ & 312.22 & $\mathrm{a}$ & 360.00 & $\mathrm{a}$ \\
\hline $\mathrm{DO}(\mathrm{mg} / \mathrm{l})$ & 3.14 & $\mathrm{a}$ & 3.11 & $\mathrm{a}$ & 3.54 & $\mathrm{a}$ \\
\hline $\mathrm{DHL}(\mathrm{mg} / \mathrm{l})$ & 1233.00 & $\mathrm{~b}$ & 1246.00 & $\mathrm{~b}$ & 1288.00 & $\mathrm{a}$ \\
\hline $\mathrm{TDS}(\mathrm{mg} / \mathrm{l})$ & 978.78 & $\mathrm{a}$ & 964.33 & $\mathrm{a}$ & 1127.44 & $\mathrm{a}$ \\
\hline $\mathrm{NO}_{3}(\mathrm{mg} /)$ & 0.01 & $\mathrm{a}$ & 0.02 & $\mathrm{a}$ & 0.01 & $\mathrm{a}$ \\
\hline Kekeruhan $(\mathrm{NTU})$ & 29.00 & $\mathrm{a}$ & 26.08 & $\mathrm{ab}$ & 22.80 & $\mathrm{~b}$ \\
\hline Zat Organik (mg/l) & 3.59 & $\mathrm{c}$ & 4.13 & $\mathrm{~b}$ & 4.73 & $\mathrm{a}$ \\
\hline
\end{tabular}

Keterangan :

1) Rerata yang diikuti huruf sama pada baris yang sama berarti tidak berbeda nyata pada taraf $5 \%$ DMRT

2) Faktor perlakuan adalah : (T), terdiri atas perilaku Pasir-Lempung (media berbutir dan berpori) yaitu : Pasir (T1); Lempung (T2) ; Lempung dicampur dust arang tempurung (T3).

Tabel 3 terlihat bahwa hanya sifat air limbah TSS dan Zat Organik, yang menunjukkan pengaruh berbeda untuk keseluruhan perlakuan $T 1, T 2$ dan $T 3$. Umumnya diikuti oleh huruf yang sama untuk 2 perlakuan dan berarti tidak berbeda yaitu, $C O D$ pada perlakuan $T 2$ dan T3, BOD pada perlakuan T1 dan T2, DHL pada perlakuan $T 1$ dan $T 3$, sedangkan Kekeruhan pada perlakuan T2 diikuti huruf yang sama dari T1 dan T3. Sementara $\mathrm{pH}, \mathrm{DO}$, TDS dan $\mathrm{NO}_{3}$ menunjukkan ketiga perlakuan $\mathrm{T} 1, \mathrm{~T} 2$ dan T3 memberikan nilai yang hampir sama dan ditunjukkan oleh huruf yang sama mengikutinya. Ini berarti perlakuan T pada pengamatan III memberikan pengaruh sama terhadap respons output sifat air limbah pH dan $\mathrm{NO}_{3}$.

Perubahan sifat air limbah pada setiap perlakuan $\mathrm{T} 1, \mathrm{~T} 2$ dan $\mathrm{T} 3$ masingmasing pengamatan menunjukkan perbedaan yang nyata pada taraf $5 \%$ uji DMRT yaitu TSS, COD, DHL, dan Kekeruhan (Pengamatan I), COD, BOD, DHL (Pengamatan II), TSS dan Zat Organik (Pengamatan III). Sementara sifat air limbah yang lain menunjukkan nilai yang hampir sama berarti memberikan pengaruh sama terhadap respons output sifat air limbah dalam proses sanitasi lingkungan. Implikasinya dalam mengambil keputusan memberikan petunjuk dapat menggunakan salah satu media berpori dan berbutir yaitu, Pengamatan $\mathrm{I}$, ( $\mathrm{pH}$ dan $\mathrm{NO}_{3}$ dapat menggunakan $T 1, T 2$ atau $T 3 ; B O D, T 2$ atau T3; TDS, T1 atau T2 dan DO, T1 sama dengan T2 atau T3) ; Pengamatan II, (pH $\mathrm{DO}$ dan $\mathrm{NO}_{3}$ dapat menggunakan $\mathrm{T} 1, \mathrm{~T} 2$ atau T3; TDS dan Kekeruhan, T1 atau T2; Zat Organik T2 atau T3; dan TSS, T2 sama dengan T1 atau T3); Pengamatan III, (pH, DO, TDS dan $\mathrm{NO}_{3}$ dapat meng- 
Tamod, Z.E. : Filterisasi Media Berpori dan Berbutir .

gunakan $\mathrm{T} 1, \mathrm{~T} 2$ atau $\mathrm{T} 3 ; \mathrm{COD}, \mathrm{T} 2$ atau T3; BOD dan DHL, T1 atau T2; Kekeruhan $T 2$ sama dengan $T 1$ atau $T 3$ ). Secara umum hasil analisis sifat-sifat air limbah pada perlakuan perilaku pasir-lempung untuk ketiga pengamatan, setelah diper- bandingkan dengan hasil analisis awal air limbah menunjukkan nilai prosentase pengaruh yang berbeda terhadap peran sanitasi lingkungan seperti yang tersaji dalam Tabel 4.

Tabel 4. Prosentase Pengaruh Perilaku Pasir-Lempung Dalam Peran Sanitasi Lingkungan Terhadap Perubahan Rata-Rata Sifat Air Limbah Pada Berbagai Pengamatan (The Effect Procentage of Clayey-Sand Behaviour in Sanitizing the Environment Toward the Mean Changing of Waste Water Characteristics of Various Observation)

\begin{tabular}{|c|c|c|c|c|c|c|c|c|c|}
\hline \multirow[t]{2}{*}{$\begin{array}{l}\text { Sifat Air } \\
\text { Limbah }\end{array}$} & \multicolumn{3}{|c|}{$\begin{array}{l}\text { Pasir } \\
\text { (T1) }\end{array}$} & \multicolumn{3}{|c|}{$\begin{array}{l}\text { Lempung } \\
\text { (T2) }\end{array}$} & \multicolumn{3}{|c|}{$\begin{array}{c}\text { Lempung Plus Dust Arang } \\
\text { Aktif }(T 3)\end{array}$} \\
\hline & $\mathrm{P} 1$ & P2 & P3 & P1 & $\mathrm{P2}$ & P3 & $\mathrm{P} 1$ & P2 & P3 \\
\hline $\mathrm{PH}$ & $21.1+$ & $21.1+$ & $18.8+$ & $21.1+$ & $18.6+$ & $17.9+$ & $20.4+$ & $21.6+$ & $19.1+$ \\
\hline TSS (mg/l) & $90.2-$ & 69.8 - & $80.7-$ & $93.2-$ & $60.8-$ & $86.5-$ & 90.9 & $51.1-$ & $77.3-$ \\
\hline $\begin{array}{l}\mathrm{COD} \\
(\mathrm{mg} / \mathrm{l})\end{array}$ & $91.1-$ & $76.7-$ & $70.3-$ & 74.0 & 47.1 - & $32.4-$ & 64.0 - & $23.6-$ & $22.7-$ \\
\hline $\begin{array}{l}\mathrm{BOD} \\
(\mathrm{mg} / \mathrm{l})\end{array}$ & $94.8-$ & $87.2-$ & $78.9-$ & $83.9-$ & $68.7-$ & 51.3- & $78.9-$ & $54.5-$ & $43.8-$ \\
\hline $\begin{array}{c}\text { DO } \\
(\mathrm{mg} / \mathrm{l})\end{array}$ & $13.7+$ & 15.4 - & 39.6 - & $19.2-$ & $16.0-$ & $40.2-$ & $8.1+$ & $15.4-$ & $31.9-$ \\
\hline $\begin{array}{l}\mathrm{DHL} \\
(\mathrm{mg} / \mathrm{l})\end{array}$ & $6.2+$ & $10.2+$ & $12.1+$ & $14.4-$ & $23.0+$ & $13.3+$ & $33.5+$ & $44.4+$ & 17.1 - \\
\hline $\begin{array}{c}\text { TDS } \\
(\mathrm{mg} /)\end{array}$ & $37.2-$ & $34.6-$ & $2.1-$ & $32.6-$ & $37.9-$ & 3.6 - & 16.6 - & 20.8 - & $12.7+$ \\
\hline $\begin{array}{c}\mathrm{NO}_{3} \\
(\mathrm{mg} / \mathrm{l}) \\
\end{array}$ & $9.9-$ & 0.0 & $99.2-$ & $14.9-$ & $34.7-$ & 98.3- & $20.6+$ & 14.1 - & 99.2 - \\
\hline $\begin{array}{l}\text { Kekeruhan } \\
\text { (NTU) }\end{array}$ & $86.2-$ & $23.0+$ & $42-$ & 70.1 & $29.2+$ & 47.8 - & 76.8 - & $53.6+$ & $54.4-$ \\
\hline $\begin{array}{l}\text { Zat Orgnik } \\
(\mathrm{mg} /)\end{array}$ & -85.1 & $68.3-$ & $90.5-$ & $72.1-$ & $57.1-$ & 89.1 - & $73.5-$ & 52.4 & 87.6 - \\
\hline
\end{tabular}

Keterangan : $(-)$ \% Penurunan ; $(+)$ \% Kenaikan

Filter pasir yang digunakan mempunyai permeabilitas sangat cepat (2 liter/ menit) dengan bahan organik dan KTK rendah, sementara lempung yang digunakan berasal dari tanah antara andosol ke latosol yang mempunyai permeabilitas cepat (2,4 liter / menit), setelah dibuat dalam bentuk briket dengan bahan organik rendah dan KTK sedang. Jika diperhatikan sifat filter yang digunakan merupakan anasir yang sangat berperan dalam menyaring, menyangga dan mengalihrupakan limbah cair. Pasir mempunyai fungsi penyaring cukup baik (bahan tersuspensi menurun drastis $69.8-96.0 \%$ untuk ke- tiga pengamatan dari analisis limbah semula seperti dalam Tabel 4. Penurunan tersebut (Tabel 4) diikuti pula oleh penurunan BOD (78.9 - $94.8 \%)$, COD (70.3- $91.9 \%)$, TDS (2.1-37.2\%), zat organik $(68.3-90.5 \%)$ dan $\mathrm{NO}_{3}$ sampai $99.2 \%$. Seiring pula meningkatnya $\mathrm{pH}$ ke arah netral (18.8 -21.2 \%), DHL (6.2 $12.1 \%$ ). Kenyataan itu menunjukkan pasir mempunyai kemampuan melepaskan kesadahan pada filtrat karena senyawa silika dan oksigen yang dalam air limbah dapat berupa koloid yang mengikat $\mathrm{OH}^{-}$ pada permukaan membentuk lapisan yang bermuatan $(-)$ di pihak lain pasir 
mampu melakukan penyerapan $\mathrm{Fe}^{2+}$ oleh lapisan $\mathrm{OH}^{-}$, disamping terjadi pertukaran ion. Secara umum, tolok ukur tersebut menunjukkan fungsi pasir sebagai penyangga dan pengalihrupa dari limbah yang diberikan. Adanya perubahan menunjukkan fungsi instrumen sanitasi lingkungan berjalan baik.

Lempung juga mempunyai kemampuan sebagai penyaring. Pada Tabel 4 terlihat pengamatan I - III bahan tersuspensi tersaring 60.8 - $93.2 \%$ dan untuk perlakuan lempung plus dust arang tempurung bahan tersuspensi tersaring 51.1 $90.9 \%$. Ke dua perlakuan tersebut masing-masing diikuti oleh penurunan variabel lain seperti COD (32.4 - $74.0 \%$ dan $22.7-64.0 \%)$, BOD $(51.3-83.9 \%$ dan $43.8-78.9 \%)$, zat organik (57.1 - $89.1 \%$ dan $52.4-87.6 \%$ ). Kenyataan pada pasir sama juga untuk lempung yang menunjukkan fungsi lempung sebagai penyangga dan pengalihrupa dari limbah yang diberikan dan ditunjukkan dari perubahan sifat air limbah, sementara unsur $\mathrm{Fe}, \mathrm{Ca}$, $\mathrm{mg}$ dan $\mathrm{Na}$ sebagian besar menempati posisi $\mathrm{H}^{+}$sehingga mengurangi aktivitas perengkahan. Hillel (1980) menyatakan bahwa pada lempung sangat mudah membentuk ikatan senyawa organik-mineral. Dipihak lain Siswiyati, Tejoyuwono dan Suhardjo (1999) menyatakan bahwa lempung dapat mengikat logam-logam, karena dalam lempung (bermuatan negatif) terjadi pertukaran kation antara kompleks tanah dan limbah. Kation akan cepat berbaur dengan elektrolit (Paruntu 1988), sehinga memperlambat pergerakan air limbah yang mengandung kation. Ini memungkinkan beberapa sifat kimia (logam) ikut tertahan bersama-sama dengan TDS pada zarah media, disamping bahan tersuspensi tersaring, bahan terlarutkan juga ikut berubah bentuk dan tertinggal dalam media filter, menunjukkan proses alihrupa berlangsung (Nilai TDS menurun). Ini berarti pula fungsi instrumen sanitasi lingkungan berjalan baik. Di pihak lain, keberadaan pori mikro pada filter lempung sering menyebabkan proses penyaringan berjalan lambat dan bahkan terhenti karena porinya tersumbat oleh koloid limbah. Sutanto (1988) dalam Mulyono, Notohadiningrat dan Soekodarmodjo (1993) menyatakan tekstur lempung mempunyai kemampuan penyanggaan tanah yang sangat besar dengan mineralnya bertipe $2: 1$. Oleh sebab itu dalam penelitian ini lempung dijadikan briket (campuran perekat kanji yang mengandung senyawa karbohidrat kompleks).

Dari ketiga pengamatan (Tabel 1, 2 dan 3), perlakuan pasir dan lempung dengan absorban dust arang tempurung sebagai instrumen sanitasi lingkungan dalam bentuk media berbutir dan berpori, telah menunjukkan adanya perubahan sifat air limbah mie instan Indofood dengan menurunnya nilai kepekatannya setelah berlangsung proses alihrupa diatas. Ini berarti kepekatan limbah akan terendapkan ketika melewati media pasir-lempung yang dimaksud. Notohadiprawiro (1975) menyatakan bahwa air yang terlalu pekat akan melonggok pada tanah termasuk di dalamnya media yang telah diperlakukan. Namun sebaliknya pula air yang terlalu encer akan menyebabkan pelindian.

Adanya arang aktif yang dicampur dengan lempung dalam bentuk briket merupakan adsorban yang dapat menyerap zat-zat warna dari larutan. Peristiwa penyerapan tersebut yang dikenal sebagai adsorpsi menurut Mandey (1997) disebabkan oleh gaya tarik molekul pada permukaan adsorben yang menyerab zat terlarut. Kekompleksan zat terlarut akan menentukan kekuatan daya serab oleh adsorben. Dalam penelitian ini, nilai zat terlarut menurun dari nilai analisis awal dan hanya perlakuan arang pada pengamatan III yang meningkat. Ini berarti zat terlarut 
pada air limbah cenderung homogen untuk pengamatan III, karena makin kompleks zat yang terlarut, makin kuat diserab oleh adsorben dan berbanding terbalik pada temperatur yang tinggi. (Ketaren 1986 dalam Mandey 1997). Kemungkinan lain karena dicampurnya dust arang tempurung dengan lempung telah bertentangan dengan fungsi adsorben yang mempunyai kemampuan menyerab kotoran-kotoran yang tidak dikehendaki. Dipihak lain, pada permukaan arang diduga terjadi pertukaran kation, karena arang yang banyak mengandung $\mathrm{Ca}^{2+}$, $\mathrm{mg}^{2+}, \mathrm{Na}^{2+}$, dan $\mathrm{K}^{2+}$ akan terikat pada lapisan (+), sehingga air filtrat diduga akan mengalami penambahan kesadahan.

Dalam lingkungan tertentu (potensial redoks meningkat), adanya kontak antara lempung dengan limbah, memungkinkan terjadinya percepatan proses oksidasi sulfida dengan mereduksi besi feri (Patrick dan Reddy 1978 dalam Mulyono, Notohadiningrat dan Soekodarmodjo 1993) dari tanah, apalagi nilai sulfida analisis awal pada air limbah menunjukkan nilai diatas persyaratan yang ditetapkan.

$2 \mathrm{FeS}_{2}+15 / 2 \mathrm{O}_{2}+4 \mathrm{H}_{2} \mathrm{O} \longrightarrow \mathrm{Fe}_{2} \mathrm{O}_{3}+4 \mathrm{SO}_{4}{ }^{2}+8 \mathrm{H}^{+}$

Oksidasi tersebut akan menghasilkan asam dan menurunkan $\mathrm{pH}$ air lindian. $\mathrm{pH}$ tinggi kation berubah menjadi bentuk oksida dan hidroksida yang tidak larut. Sifat dari media tersebut sebagai pengikat dan mempertukarkan kation dan kemampuan menetralkan kation yang masuk ke dalamnya (Siswiyati, Tejoyuwono dan Suhardjo 1999), sehingga pencemaran dapat ditekan. Perubahan $\mathrm{pH}$ air limbah setelah dilakukan filterisasi seperti yang dituliskan oleh Bohn, Brian dan Connor (1973) menilai kecenderungan meningkat, $\mathrm{pH}$ alkali berkaitan dengan kadar garam. Hal ini ditunjukan oleh nilai DHL. Tinggi- nya nilai $\mathrm{DHL}$ menyebabkan $\mathrm{pH}$ berkisar diatas netral (Mulyono, Notohadiningrat dan Soekodarmodjo 1993). Dalam penelitian ini, nilai DHL cenderung meningkat seiring dengan nilai $\mathrm{pH}$ meningkat ke arah netral. Penggunaan filter campuran dust arang (T3) cenderung lebih tinggi konsentrasi garam yang dihasilkan, karena arang mengandung abu-abu dan garam-garam lain diantara butiran arang yang mengandung oksida-oksida logam alkali dan alkali tanah $\mathrm{Na}_{2} \mathrm{O}, \mathrm{K}_{2} \mathrm{O}, \mathrm{CaO}$ dan ikut terlarut ke bentuk basa kuat, $\mathrm{NaOH}, \mathrm{KOH}, \mathrm{Ca}(\mathrm{OH})_{2}$. Penelitian Saeni dkk. (1998) membuktikan bahwa dari saringan arang tempurung berpotensi menaikan garam-garam terlarut dalam filtrat. Menyebabkan $\mathrm{pH}$ berkisar diatas netral (Mulyono, Notohadiningrat dan Soekodarmodjo 1993).

Pada dasarnya ketiga perlakuan mempunyai kemampuan sanitasi berbeda yang menunjukkan situasi buangan air limbah terbolehkan dan tidak membahayakan lingkungan, walaupun nilai $C O D$ belum mencapai nilai di bawah yang telah dipersyaratkan. Pengaruh jenis perlakuan (T) terhadap sifat-sifat air limbah pada pasir (T1) mempunyai kelolosan yang paling besar, kemudian lempung (T2) dan diikuti lempung plus dust arang tempurung (T2), sehingga sifat-sifat limbah yang dianalisis juga menunjukkan perbedaan yang nyata dengan urutan $\mathrm{T} 1-\mathrm{T} 2-\mathrm{T} 3$. Dipihak lain jika diperhatikan tanah lempungan mempunyai kemampuan sanitasi lebih tinggi mengingat pori mikro yang dominan, namun karena permeabilitasnya rendah maka volume air yang lolos lebih sedikit atau kapasitas rendah. Kenyataan ini menunjukkan sifat fisik media akan menentukan kualitas penyaringan, sementara koloid dari media akan menentukan penyanggaan karena $\mathrm{pH}$ berubah menghasilkan $\mathrm{OH}$ (hidroksida) yang ditunjukkan dari besarnya KTK, kadar zat organik, dan kandungan lempung serta peng- 
alihrupaan limbah. Namun baik filter pasir maupun lempung dan lempung campuran dust arang tempurung mampu mempercepat proses penurunan $\mathrm{BOD}$ dan $\mathrm{COD}$ dan tidak bermasalah pada kemasaman, sehingga dapat dikatakan bahwa media berpori dan berbutir dari pasir (T), lempung (T2) dan Lempung campuran dust arang aktif (T3) dapat digunakan sebagai instrumen sanitasi lingkungan terhadap limbah cair mie instan Indofood.

\section{KESIMPULAN}

1. Penggunaan media berpori dan berbutir dari pasir (T1), lempung (T2) dan lempung campuran dust arang aktif (T3), dapat digunakan sebagai filter dalam instrumen sanitasi lingkungan terhadap limbah cair berbasis bahan organik mie instan, karena di samping pasir (T1) mempunyai kelolosan yang paling besar, kemudian lempung (T2) dan diikuti lempung plus dust arang tempurung (T2), juga membuktikan adanya perubahan sifat air limbah dengan menurunnya nilai kepekatan

2. Filter yang digunakan merupakan anasir yang sangat berperan dalam menyaring, menyangga dan mengalihrupakan limbah cair. Pasir mempunyai fungsi penyaring cukup baik (bahan tersuspensi menurun drastis $69.8-96.0 \%$ dan diikuti oleh penurunan BOD $(78.9-94.8 \%)$, COD $(70.3-91.9 \%)$, TDS $(2.1-37.2 \%)$, zat organik $(68.3-90.5 \%)$ dan $\mathrm{NO}_{3}$ sampai $99.2 \%$ dan meningkatnya pH ke arah netral (18.8-21.2\%), DHL $(6.2-12.1 \%)$ pada pengamatan I-III.

3. Lempung menunjukkan fungsi sebagai penyaring, penyangga dan pengalihrupa dari limbah yang diberikan dan ditunjukkan dari perubahan sifat air limbah yaitu pada pengamatan 1III bahan tersuspensi tersaring 60.8 $93.2 \%$ dan untuk perlakuan lempung plus dust arang tempurung bahan tersuspensi tersaring 51.1 $90.9 \%$. Ke dua perlakuan tersebut masing-masing dilkuti oleh penurunan variabel lain seperti $\mathrm{COD}$ (32.4 $74.0 \%$ dan $22.7-64.0 \%$ ), BOD (51.3 - 83.9\% dan $43.8-78.9 \%$ ), zat organik $(57.1-89.1 \%$ dan $52.4-87.6 \%)$.

\section{DAFTAR PUSTAKA}

Anonimous.,2002. Filter Air dengan Briket Media Berbutir. Pusat Penelitian dan Pengembangan Permukiman. Bandung.www.kbw.go.id/balitbang/ puskim.

Bohn, H.L., L.M. Brian, and G. A. O.Connor., 1983. Soil Chemistry. John Wiley and Sons. New York. 329 hal.

Eckenfelder, W. W., J. Patoczka and A. T. Watkin. 1985. Waste Water Treatment. Chemical Engineering. $92(18): 60$ - 73 .

Foth, H. D. 1994. Dasar-Dasar IImu Tanah. Terjemahan Edisi ke-6. Gelora Aksara Pratama Erlangga, Jakarta.

Gaspersz, V., 1995. Metode Perancangan Percobaan. Armico. Jakarta. 472 hal.

Gomez, K. A. dan A. A.Gomez ., 1995. Prosedur Statistik Untuk Penelitian Pertanian, Ed II. Terjemahan. Universitas Indonesia. Jakarta. 
Tamod, Z.E. : Filterisasi Media Berpori dan Berbutir

Hillel, D., 1980. Fundamental of Soil Physics. Academic Press Inc. London LTD. 413 p.

Kodoatie, R., 1996. Pengantar Hidrogeologi. Andi, Yogyakarta.

Mandey L. C., 1997. Pengolahan Limbah Cair Industri Tepung Kelapa Secara Fisika, Kimia dan Biologi. Disertasi. Program Pascasarjana Universitas Airlangga. Surabaya. 199 hal.

Mulyono, N., T. Notohadiningrat dan S. Soekodarmodjo., 1993. Peranan Beberapa Jenis Tanah Untuk Sanitasi Lingkungan Terhadap Limbah Cair Pabrik Penyamak Kulit di Yogyakarta. BPPS UGM Yogyakarta. 6 (3B). hal 353 - 369.

Notohadiprawiro, T., 1999. Tanah dan Lingkungan. Direktorat Jenderal Pendidikan Tinggi Departemen Pendidikan dan Kebudayaan. Nugroho, B., 2001. Ekologi Mikroba Pada Tanah Terkontaminasi Logam Berat. Pasca Sarjana IPB Bogor. http:/rudyct.tripod.com

Paruntu, J., 1988. Dasar-Dasar Fisika Lingkungan. Fakultas Pertanian Unsrat. Manado. 288 hal.

Saeni M. S., R.T.M Sutamihardja, J. Sukra, S Soemarto, T. Ungerer dan Barizi., 1998. Kemampuan Saringan Pasir, ljuk dan Arang dalam Meningkatkan Kualitas Fisik dan Kimia Air. Forum Pascasarjana IPB. Bogor. II (1). hal. 27 47.

Siswiyati A.S., N. Tejoyuwono dan A. J. Suhardjo., 1999. Perilaku Tanah Sebagai Instrumen Sanitasi Lingkungan terhadap Pencemaran Sampah Kota. Teknosains, Pascasarjana UGM. Yogyakarta. 12 (3) hal. 323 - 331. 
Lampiran 1. Gambar Histogram Rata-Rata Sifat Air Limbah Setelah Dilakukan Filterisasi Pasir-Lempung Pada Ketiga Pengamatan Dimana Ao (Hasil analisis awal), T1, T2 dan T3 (Hasil Analisis Perlakuan Pasir, Lempung dan Lempung Plus Arang)

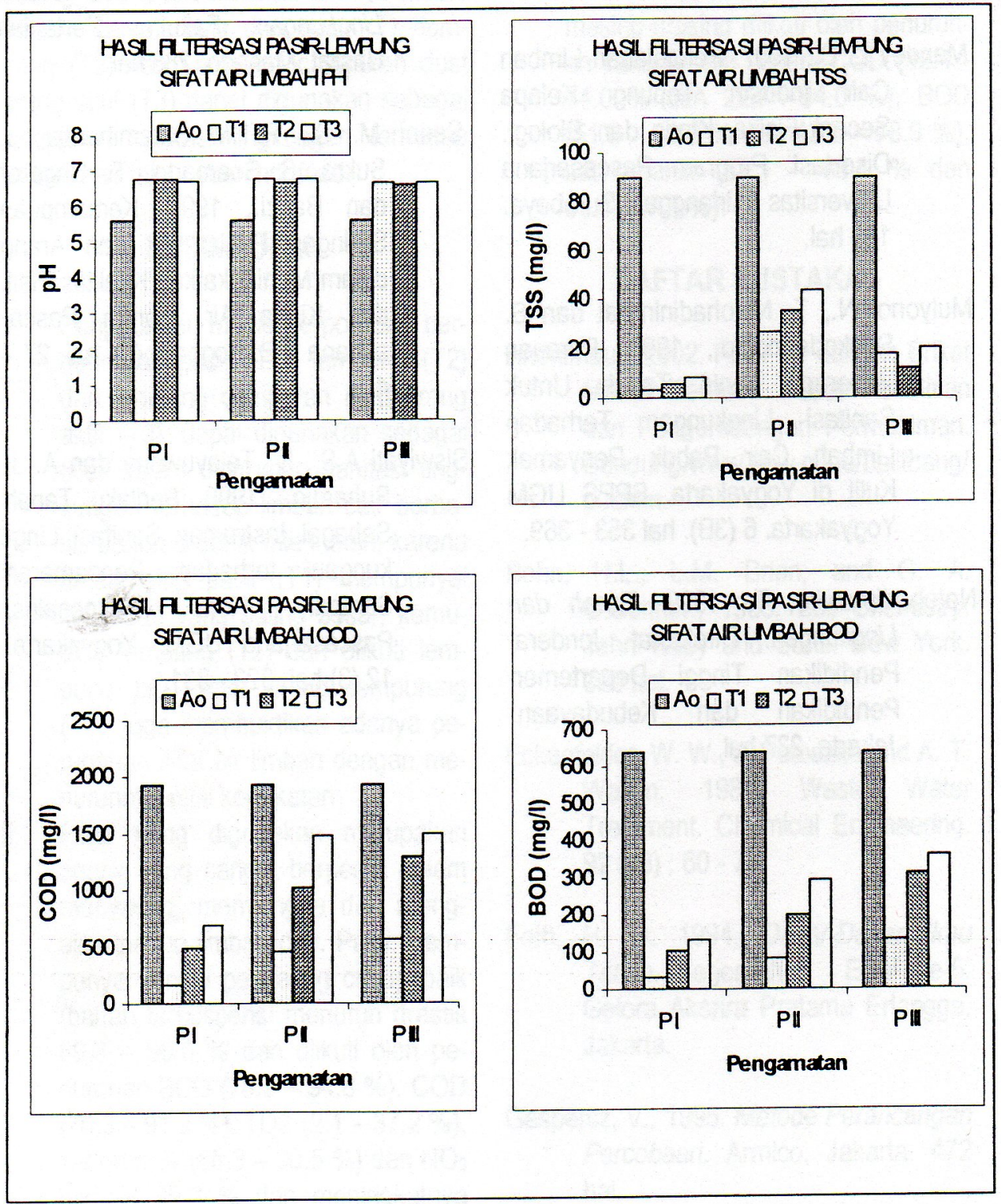


Tamod, Z.E. : Filterisasi Media Berpori dan Berbutir

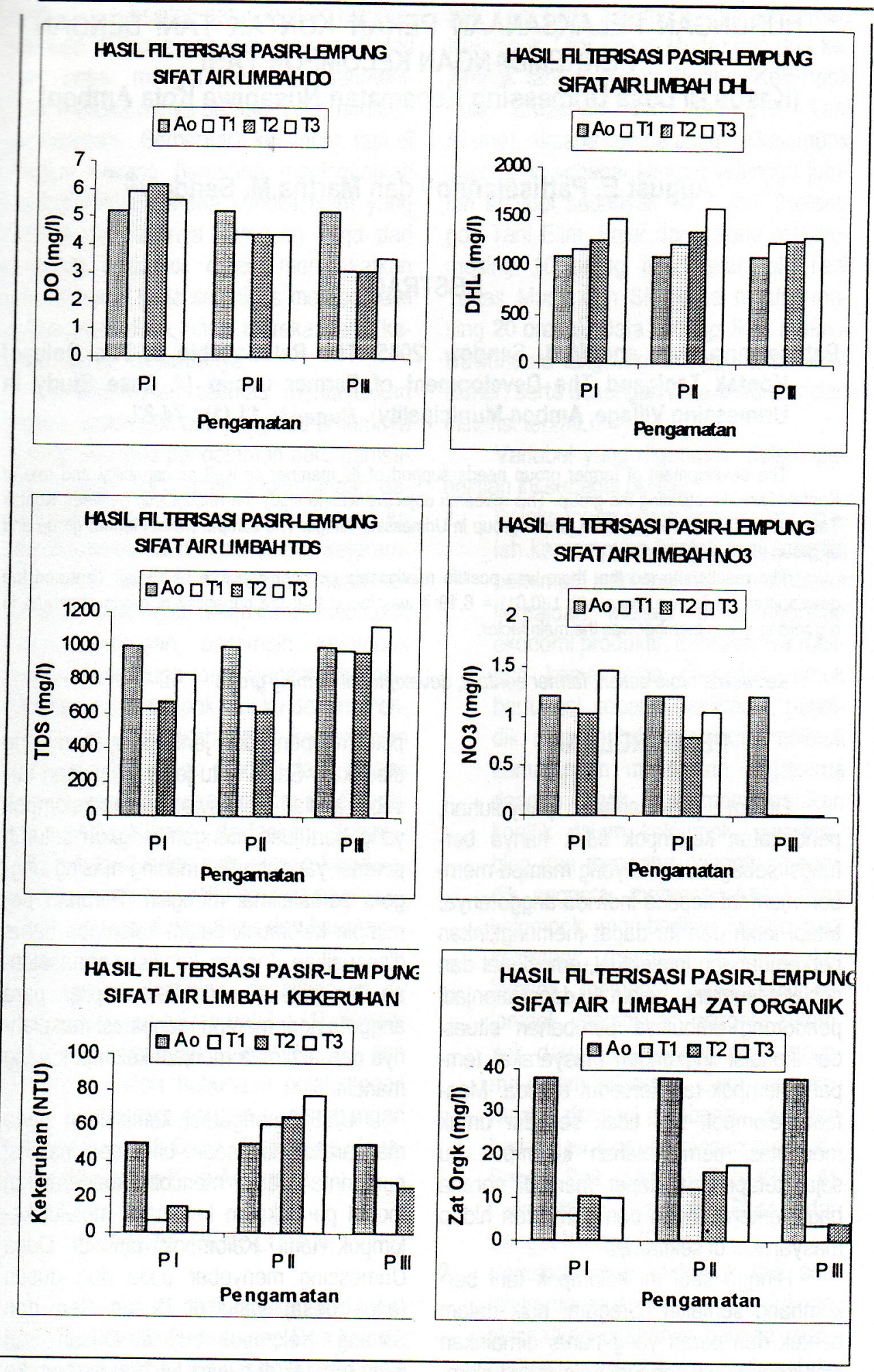

